\title{
Sustainable banking and possibilities of its application in case of agricultural credit support: world experience and prospects for the Russian Federation
}

\author{
Svetlana Urazova, ${ }^{1, *}$ \\ ${ }^{1}$ Rostov State University of Economics, 69, Bolshaya Sadovaya str., 344002, Rostov-on-Don, Russia
}

\begin{abstract}
The article describes the features of bank lending to agriculture, taking into account the focus on achieving sustainable development goals, based on world experience synthesis in the application of sustainable banking, including agricultural lending, recommendations were developed aimed at developing bank lending to agriculture in the Russian Federation based on the ideas of sustainable banking.
\end{abstract}

\section{Introduction}

The concept of sustainable development arose in the second half of the 20th century. Against this background, the idea of sustainable banking and sustainable financing arose. The idea of sustainable development was reflected in the adopted by the UN in 2015 «The 2030 Agenda for Sustainable Development» [1], containing sustainable development goals. The SDGs are based on the premise that development must be economically, socially and environmentally sustainable. Also, in $2015 \mathrm{UN}$ member countries have adopted the Addis Ababa Program of Action for the Third International Conference on Financing for Development [2].

One of the important aspects of ensuring sustainable development is changing the approach to agricultural production, increasing the importance of environmental conservation, activation of bank lending of the projects, focused on improving the environmental situation, introduction of energy-saving technologies, sustainable agriculture development. That is why an important activity of banks focused on achieving sustainable development goals is to support agriculture and at present, the formation of this practice is being observed in various countries of the world, including the Russian Federation. In this regard, it is especially important to pay special attention to the development of recommendations aimed at the establishment and development of agricultural lending based on the sustainable bank principles in Russia.

The issues of sustainable banking are given attention in the works of a number of scientists, including Kanaev A.V. and Kanaeva O.A. [3], Taruna D.R. and Mahdevi T.P. [4], Yip A.W.H. and Bocken N.M.P. [5], Carlucci, D., Ferreira, F.A.F., Schiuma, G., Jalali, M.S., and António, N.J.S. [6].

\footnotetext{
*Corresponding author: urazova@inbox.ru
} 
The role of development banks in implementing the sustainable development ideas is discussed in documents of international organizations, as well as studies of a number of scientists - Yuana F., Gallagherb K.P. [7].

The need and effectiveness of socially responsible activities of banks even in times of economic crisis are shown in the work of Selmier W.T. [8].

Increasing the importance for investors of the companies' activities aimed at achieving sustainable development goals is noted in the work of García-Sánchez, I.-M., RodríguezAriza, L., Aibar-Guzmán, B., Aibar-Guzmán, C. [9]

At the same time, there are a number of problems of environmental and economic accounting necessary for monitoring the SDGs, which is reflected, in particular, in the work of Pirmana V., Alisjahbana A.S., Hoekstra R. and Tukker A. [10]

The importance of banks' activities aimed at achieving the SDGs to increase confidence in banks and improve their image has been noted in the works of a number of scientists: Nosratabadi S., Pinter G., Mosavi A. and Semperger S. [11], Miralles-Quirós, M.M., Miralles-Quirós, J.L., Redondo-Hernández, J. [12], Ibe-enwo G., Igbudu N., Garanti Z., Popoola T. [13], Alonso-Canadas, J., Saraite-Sariene, L., Haro-de-Rosario, A., Caba-Perez, MD. [14], Burhanudin B., Ronny R., Sihotang E.T. [15]

The stability of the positive impact of such activities on improving the financial performance of organizations is shown in the work of Friede G., Busch T., Bassen A. [16]

Gonenc H. and Scholtens B. [17] showed that banks with high capital adequacy ratios also have a higher level of liability indicators.

Gallego-Álvarez, I., Pucheta-Martínez, M.C. [18], after conducting a study, concluded, that banks operating in countries with a coordinated market economy (CME) deal with environmental issues to a greater extent than banks operating in countries with a liberal market economy (LME).

Anshari M., Almunawar M.N., Masri M., Hamdan M. [19] in their study noted the importance of bank lending to farmers. And digital market with Fintech support may, in their opinion, contribute to more sustainable agricultural financing.

The aim of the study, the results of which are reflected in this article, was to develop recommendations aimed at the development of bank lending to agriculture in the Russian Federation based on sustainable banking. The goal has determined the need to solve the following range of tasks: revealing the features of bank lending to agriculture, taking into account the focus on achieving sustainable development goals; generalization of world experience in applying sustainable banking, including agricultural lending; generalization of Russian experience in sustainable banking; identification of prospects for the development of bank lending to agriculture in the Russian Federation based on sustainable banking.

\section{Materials and Methods}

To conduct the study, the work used the World Bank database on indicators demonstrating progress towards achieving the sustainable development goals. To conduct the study, the data of a number of international organizations, a number of banks focused on supporting the sustainable banking transition practice were considered, as well as support of agriculture. At the same time, information was considered both on the composition of these organizations and on indicators of agricultural lending.

In particular, the information of the World Bank Group, a number of UN agencies, Network of Central Banks and Supervisors for Greening the Financial System (NGFS), Global Alliance for Banking on Values (GABV), Global Agriculture and Food Security Program (GAFSP), UN Global Compact, and UN Global Compact Russia. 


\section{Results}

The most important features of bank lending to agriculture, taking into account the focus on achieving sustainable development goals, are currently associated: firstly, with a range of problems to be solved due to the transition of banks to a sustainable banking business model, oriented on the SDGs destination; secondly, with a specific variety of banks that support the sustainable banking ideas and are accordingly oriented towards achieving sustainable development goals (the following main groups of banks can be distinguished: central banks of various countries; international and national development banks; other banks operating both in individual countries and in the international arena. The activities of banks of each of these groups related to the achievement of the SDGs have its own specifics); thirdly, the specifics of agriculture, taking into account the SDGs. Bank lending to agriculture, aimed at achieving sustainable development goals, is especially significant associated with the following main aspects: a) promoting environmental sustainability; b) agricultural productivity improvement. The latter aspect is especially important for the poorest countries, where the solution to this problem is directly related to overcoming hunger and poverty. The World Bank and its affiliates are actively involved in solving this problem. It is the World Bank, as one of the largest international development banks, focused on the provision of bank lending aimed at supporting agriculture. Bank lending support for agriculture, focused on achieving sustainable development goals, is provided not only by the World Bank, but also by other international and national development banks. Moreover, lending to agriculture is carried out not only through the implementation of special credit support programs for agriculture, but also through lending to agricultural producers as part of infrastructure development support programs, environmental (green) projects, small and medium business, female entrepreneurship, poverty alleviation programs.

The largest volumes of loans provided by IBRD and IDA (members of the World Bank) to support for ahriculture, fisheries and forestry in fiscal 2019 fell on Africa, the second place in terms of lending to these industries was taken by South Asia (table 1).

There is no significant trend towards an increase in the volume and share of the reserved funds of the IBRD and IDA to support agriculture, fisheries and forestry in the total amount of funds reserved for all sectors for the period from 2015 to 2019 financial years (table 2).

Table 1. Volumes and share of lending provided by the IBRD and IDA to support agriculture, fisheries and forestry, by region of the world for fiscal year 2019 [20].

\begin{tabular}{|l|c|c|c|}
\hline Region of the world & $\begin{array}{l}\text { Total lending } \\
\text { to all sectors, } \\
\text { billion US } \\
\text { dollars }\end{array}$ & $\begin{array}{l}\text { Share in } \\
\text { agriculture, fisheries } \\
\text { and forestry, \% }\end{array}$ & $\begin{array}{l}\text { Total lending to } \\
\text { agriculture, fisheries } \\
\text { and forestry, billion US } \\
\text { dollars }\end{array}$ \\
\hline Africa & 15.0 & 12 & 1.8 \\
\hline $\begin{array}{l}\text { East Asia and the } \\
\text { Pacific }\end{array}$ & 5.3 & 5 & 0.265 \\
\hline $\begin{array}{l}\text { Europe and Central } \\
\text { Asia }\end{array}$ & 4.3 & 11 & 0.473 \\
\hline $\begin{array}{l}\text { Latin America and } \\
\text { the Caribbean }\end{array}$ & 6.1 & 3 & 0.183 \\
\hline $\begin{array}{l}\text { Middle East and } \\
\text { North Africa }\end{array}$ & 5.5 & 0 & 0 \\
\hline South Asia & 8.9 & 13 & 1.157 \\
\hline Total & 45.1 & 8.6 & 3.878 \\
\hline
\end{tabular}


Table 2. Reserved IBRD and IDA funds for agriculture, fisheries and forestry as of fiscal 2015-2019 [20].

\begin{tabular}{|l|c|c|c|c|c|}
\hline & $\begin{array}{c}\mathbf{2 0 1 5} \\
\text { f.y. }\end{array}$ & $\begin{array}{c}\mathbf{2 0 1 6} \\
\text { f.y. }\end{array}$ & $\begin{array}{c}\mathbf{2 0 1 7} \\
\text { f.y. }\end{array}$ & $\begin{array}{c}\mathbf{2 0 1 8} \\
\text { f.y. }\end{array}$ & $\begin{array}{c}\mathbf{2 0 1 9} \\
\text { f.y. }\end{array}$ \\
\hline $\begin{array}{l}\text { Agriculture, fisheries and forestry, million US } \\
\text { dollars, including: }\end{array}$ & 3368 & 2410 & 2779 & 4003 & 3821 \\
- IBRD & 843 & 561 & 754 & 2561 & 1025 \\
- IDA & 2525 & 1849 & 2025 & 1442 & 2796 \\
\hline $\begin{array}{l}\text { Total reserves for all industries, million US } \\
\text { dollars, including: }\end{array}$ & 42494 & 45900 & 42074 & 47012 & 45123 \\
- IBRD & 23528 & 29729 & 22611 & 23002 & 23191 \\
- IDA & 18966 & 16171 & 19463 & 24010 & 21932 \\
\hline $\begin{array}{l}\text { Share of agriculture, fisheries and forestry in } \\
\text { the total amount of reserved funds, \%, }\end{array}$ & 7.92 & 5.25 & 6.61 & 8.51 & 8.47 \\
including: & & & & & \\
- IBRD & 3.5 & 1.9 & 3.3 & 11.1 & 4.4 \\
- IDA & 13.3 & 11.4 & 10.4 & 6.0 & 12.7 \\
\hline
\end{tabular}

Analyzing the list of sustainable development goals for which sustainable banking is oriented, we can conclude that credit support for agriculture is connected with the work to achieve such goals as: no poverty; zero hunger; decent work and economic growth; industry, innovation, and infrastructure; climate action; life on land.

The World Bank has compiled a database of indicators consistent with sustainable development goals, which allowed Eustachio, J.H.P.P., Caldana, A.C.F., Liboni, L.B., Martinelli, D.P. [21] to propose a systemic indicator of sustainable development for monitoring sustainable development activities.

One of the indicators included in the indicators range related to the sustainable development goals achievement, formed by the World Bank, is the indicator «agriculture, forestry, and fishing, value added per worker (constant 2010 US\$)», as shown in Figure 1, the lowest values of this indicator are in a number of countries in Africa, as well as Lao People's Democratic Republic, Vietnam, Bangladesh, Nepal, Kingdom of Bhutan, Afghanistan, Republic of Yemen [22] (table 3). Moreover, the values of the indicator in these countries are hundreds of times lower than in developed countries. Despite the growth of this indicator in the Russian Federation, it is significantly lower than the leading countries.

Table 3. Agriculture, forestry, and fishing, value added per worker (constant 2010 US\$) in countries with the highest and lowest values of this indicator [22].

\begin{tabular}{|c|c|c|c|c|c|c|c|c|c|}
\hline $\begin{array}{c}\text { Country } \\
\text { Name }\end{array}$ & $\mathbf{2 0 1 0}$ & $\mathbf{2 0 1 1}$ & $\mathbf{2 0 1 2}$ & $\mathbf{2 0 1 3}$ & $\mathbf{2 0 1 4}$ & $\mathbf{2 0 1 5}$ & $\mathbf{2 0 1 6}$ & $\mathbf{2 0 1 7}$ & $\mathbf{2 0 1 8}$ \\
\hline Burundi & 230 & 221 & 219 & 232 & 218 & 204 & 193 & 186 & 185 \\
\hline $\begin{array}{c}\text { Congo, Dem. } \\
\text { Rep. }\end{array}$ & 293 & 300 & 309 & 314 & 320 & 327 & 328 & 322 & 318 \\
\hline Madagascar & 389 & 386 & 391 & 360 & 359 & 347 & 341 & 336 & 338 \\
\hline Lesotho & 275 & 287 & 277 & 333 & 347 & 319 & 386 & 392 & 384 \\
\hline Zimbabwe & 297 & 303 & 325 & 309 & 367 & 343 & 324 & 350 & 404 \\
\hline $\begin{array}{c}\text { Central } \\
\text { African } \\
\text { Republic }\end{array}$ & 689 & 714 & 732 & 383 & 379 & 381 & 396 & 402 & 409 \\
\hline Mozambique & 384 & 396 & 397 & 404 & 415 & 425 & 430 & 432 & 432 \\
\hline Zambia & 624 & 671 & 713 & 665 & 654 & 586 & 588 & 624 & 476 \\
\hline
\end{tabular}




\begin{tabular}{|c|c|c|c|c|c|c|c|c|c|}
\hline Niger & 465 & 435 & 485 & 468 & 490 & 480 & 513 & 522 & 541 \\
\hline Uganda & 664 & 682 & 684 & 607 & 602 & 595 & 586 & 572 & 570 \\
\hline Ethiopia & 438 & 468 & 476 & 501 & 516 & 538 & 549 & 574 & 581 \\
\hline Nepal & 519 & 538 & 562 & 567 & 591 & 592 & 579 & 597 & 599 \\
\hline Rwanda & 428 & 436 & 456 & 482 & 534 & 552 & 558 & 581 & 602 \\
\hline Low income & 574 & 575 & 596 & 598 & 611 & 614 & 612 & 620 & 623 \\
\hline Guinea & 508 & 530 & 542 & 566 & 570 & 599 & 602 & 699 & 717 \\
\hline Lao PDR & 732 & 721 & 726 & 736 & 755 & 770 & 777 & 787 & 785 \\
\hline Haiti & 957 & 938 & 897 & 914 & 880 & 814 & 819 & 805 & 797 \\
\hline Yemen, Rep. & 1926 & 1574 & 1640 & 1701 & 1694 & 1354 & 1033 & 893 & 837 \\
\hline Afghanistan & 910 & 879 & 1128 & 1073 & 1016 & 909 & 918 & 916 & 844 \\
\hline $\begin{array}{l}\text { Russian } \\
\text { Federation }\end{array}$ & 9357 & 10660 & 10952 & 12056 & 12935 & 13366 & 13661 & 15886 & 15821 \\
\hline Euro area & 36293 & 38566 & 37695 & 39532 & 42289 & 43393 & 42442 & 43527 & 44100 \\
\hline Germany & 42401 & 40386 & 43486 & 47610 & 52418 & 45862 & 47302 & 46725 & 46326 \\
\hline $\begin{array}{c}\text { United } \\
\text { Kingdom }\end{array}$ & 42858 & 47837 & 44488 & 49651 & 46523 & 50962 & 48068 & 48769 & 46692 \\
\hline Spain & 43637 & 47697 & 43898 & 50338 & 49683 & 52066 & 51752 & 47492 & 49892 \\
\hline Belgium & 60724 & 63857 & 70803 & 52282 & 58275 & 71388 & 62499 & 66283 & 50062 \\
\hline Denmark & 58960 & 53164 & 55123 & 53701 & 63773 & 54769 & 44352 & 59343 & 51470 \\
\hline France & 53611 & 55708 & 50783 & 47339 & 59054 & 61161 & 50931 & 60359 & 62855 \\
\hline Finland & 55326 & 56920 & 56366 & 58351 & 60761 & 63885 & 70636 & 73390 & 75836 \\
\hline United States & 77822 & 70477 & 69503 & 84875 & 81656 & 81920 & 84251 & 79055 & - \\
\hline Netherlands & 57839 & 63729 & 64253 & 85596 & 82172 & 81760 & 84773 & 83361 & 80779 \\
\hline Australia & 70372 & 82142 & 82485 & 86803 & 81471 & 85997 & 78663 & 85454 & 82838 \\
\hline Israel & 70609 & 87060 & 73165 & 86317 & 90391 & 89567 & 94032 & 94915 & 91547 \\
\hline Canada & 68399 & 70992 & 72469 & 82642 & 79405 & 85932 & 75143 & 94000 & 95687 \\
\hline Sweden & 86743 & 92296 & 88773 & 88558 & 96195 & 94123 & 98286 & $\begin{array}{c}10546 \\
9\end{array}$ & 97612 \\
\hline Norway & $\begin{array}{c}10491 \\
8 \\
\end{array}$ & $\begin{array}{c}11593 \\
1 \\
\end{array}$ & $\begin{array}{c}12720 \\
7 \\
\end{array}$ & $\begin{array}{c}12230 \\
2 \\
\end{array}$ & $\begin{array}{c}12711 \\
7 \\
\end{array}$ & $\begin{array}{c}13366 \\
1 \\
\end{array}$ & $\begin{array}{c}12096 \\
0\end{array}$ & $\begin{array}{c}12733 \\
7 \\
\end{array}$ & $\begin{array}{c}12768 \\
9\end{array}$ \\
\hline
\end{tabular}

Thus, credit support for agriculture should be carried out in various aspects and is an important area of sustainable banking. It should be taken into account that there is a specificity of bank credit support for agriculture in developed and developing countries, as well as countries with a transitive economy. And this specificity is determined by the level of development of agriculture in the country, the possibilities of processing agricultural products, the socio-economic situation of the population in rural regions of the country. As for developed countries, in this case, features of agricultural credit support are also associated with a focus on supporting agricultural producers, trading organizations, enterprises processing agricultural products, as well as trade organizations in support of developing countries. Vivid example of such a policy is the activity of national development banks, which are created in developed countries, but are focused on supporting agriculture not only in their countries, but also in developing countries. This 
approach is typical, in particular, for the Dutch Development Bank (FMO), demonstrating in its reports information on the results in achieving the sustainable development goals, credit support for agriculture [23]. German Development Bank (KfW) and KfW Group generally targeting SDGs support developing countries. Wherein KfW a map of sustainable financing was developed, reflecting the bank's focus on all 17 goals of sustainable development, and assuming support of agriculture as one of the areas of activity [24]. In order to support the activities of national development banks and other organizations providing green financing in Latin America and the Caribbean, the Green Finance LAC (GFL) was developed. According to the text of the report, prepared in 2019, one of the important areas of green financing is to support sustainable financing (including bank lending) of Latin America and the Caribbean agriculture [25].

A number of international development banks (World Bank Group, African Development Bank, Asian Development Bank, Inter-American Development Bank) are involved in the implementation of the Global Agriculture and Food Security Program (GAFSP) [26], being a global partnership designed to combat hunger, malnutrition and poverty in developing countries to achieve sustainable development goals. GAFSP supports sustainable agriculture, focusing on farmers, especially women and youth. GAFSP is a financial intermediary fund, the Coordination Group of which is located in the World Bank.

The International Finance Corporation, a member of the World Bank Group, pays special attention to sustainable agribusiness and its financing opportunities [27].

IFC developed The Global Map of Environmental \& Social Risk in Agro-commodity Production (GMAP)» [28], allowing users to conduct quick environmental and social assessments related to trade and short-term financing, necessary for making responsible financing decisions, including granting bank lending and managing the risks arising from it. This tool allows to access detailed risk analysis reports, as well as risk management guides.

In the implementation of measures aimed at financing the sustainable development goals achievement, the central banks of various countries are also included, which has become especially significant since its inception in December 2017 by the organization of Network of Central Banks and Supervisors for Greening the Financial System (NGFS). To the end of 2019, it consisted of 54 members and 12 observers [29].

Banks operating in various countries that are oriented towards achieving sustainable development goals are included in international organizations aimed at disseminating banking practices taking into account these goals. One of such organizations has become the Global Alliance for Banking on Values (GABV), developed in 2009 and which is a network of banking institutions from around the world, established to change banking systems, increase its transparency, maintain economic, social and environmental sustainability. To the end of 2019 this organization already included banks in Europe, North America, Latin America, Asia Pacific and Africa [30]. In this regard, it should be noted that the orientation of banks to the SDGs achievement has led to the emergence in the world banking practices of concepts such as value-based banking, socially responsible banking, responsible banking, sustainable banking, ESG (Environmental, Social, Governance) banking, environmental banking, ethical banking, green banking. In the work of Serrano Pérez M.E. [31]. Social and Ethical Banking Index proposed by the author based on data from banks, participated in Global Alliance for Banking on Values (GABV). However, the concept of «sustainable banking» has become the most comprehensive and widespread. In 2012 there was established Sustainable Banking Network (SBN), established under the auspices of the International Finance Corporation and a community of financial sector regulatory bodies and banking associations of developing countries committed to promoting sustainable financing in accordance with international best practices. According to the text of the report of this organization, released in 2019, agricultural support has become one of the important areas of sustainable banking [32]. 
Huge credit investments are required to increase agricultural productivity, efficiency and sustainability. And banks of various countries, focusing on achieving the goals of sustainable development and actually moving on to implement the ideas of sustainable banking, carry out lending to agriculture within its framework. So, Deutsche Bank invests in agriculture to increase productivity and sustainability [33]. Wherein, Deutsche Bank offers lending to farmers and also supports the activities of the AATIF fund, which promotes food security in Africa. The Bank is guided in its activities that in order to solve the problem of food security and successfully combat hunger in the world, agricultural production should double and agriculture should change through the creation of a food production and distribution system that is fairer, more environmentally friendly and more sustainable. This requires innovative models and new intelligent technologies to increase productivity and efficiency. It ranges from irrigation systems and new technologies to the market for sustainable food products. Along with direct investment in agriculture, Deutsche Bank provides lending to agricultural enterprises, trading companies and food producers around the world. In the banking group Crédit Agricole Group sustainable banking group was established, supporting since 2009 social and environmental projects in several areas, one of which is agriculture [34]. The Bank provides support to rural communities in poor countries, focuses on supporting agroforestry, and provides lendinf for projects aimed at reducing carbon dioxide emissions.

In the European Union in 2018 there was established the Technical expert group on sustainable finance (TEG) to advise on implementation the Action Plan: Financing Sustainable Growth [35], adopted by the European Union in 2018, which includes, among other things, support for sustainable agriculture [35]. in the report «Green finance taxonomy», prepared and published by TEG in 2019, a unified terminology system in the field of financing for sustainable development is proposed. It is planned to integrate this taxonomy into the legislation of the European Union until December 31, 2022. This taxonomy includes economic activities that can make a significant contribution to the achievement of environmental goals related to sustainable development. And one of these types of economic activity is recognized «agriculture, forestry and fisheries», which key industries are: growing annual and perennial crops; animal breeding; logging and forest management; agricultural recovery. Thus, in the European Union, support for agriculture has been declared an important area of financing sustainable development. Moreover, a significant role in this process will belong to banks.

In September 2019, a fundamentally new event took place, bringing the banking business focused on achieving sustainable development goals to the level of international agreements of a global scale. It's about UN level adoption of the Principles for Responsible Banking (PRB) [36]. These principles are formulated as follows: adjustment; definition of impact and goals; customers and buyers; parties concerned; management and culture; transparency and accountability. Initially, these principles were signed by 130 banks from 49 countries with total assets of more than $\$ 47$ trillion, and were approved in September 2019 in New York during the annual United Nations General Assembly [37]. Later, other banks began to express their commitment to these principles. To April 2020, the number of banks that have signed these principles has increased to 170 [38]. According to the latest principle of responsible banking, a bank that has joined the «Principles for Responsible Banking» must provide information on its implementation within the first 18 months after signing and every year thereafter [36]. In March 2020, UNEP FI Banking Group launched a portfolio impact analysis tool for banks that adhered to these principles. At the same time, the Guidance document on the analysis of the impact associated with the implementation of the principles of responsible banking was approved [39].

In the Russian Federation, Vnesheconombank (now VEB.RF) primarily demonstrates commitment to the ideas of sustainable development in various aspects, PJSC Sberbank, 
«VTB Bank» (PJSC), JSC «Alfa Bank», PJSC KB «Center Invest». The relevant reports of these banks are presented not only on their official websites, but also in «National Register and Library of Corporate Non-Financial Reports», created by the Russian Union of Industrialists and Entrepreneurs and including social, environmental, integrated, industry reports, reports on the sustainable development of Russian companies belonging to various industries and fields of activity.

Russian banks became participants of the UN Global Compact and UN Global Compact Russia. «UN Global Compact» was signed in 2000 and this initiative started, and in 2015 it joined the process of implementing the SDGs and by January 2020. UN Global Compact supported by more than 10,000 companies from 160 countries [40]. UN Global Compact has become the world's largest corporate sustainability initiative. To 2020, among 69 Russian participants of UN Global Compact there are no agricultural companies, and only two Russian banks: PJSC «Sovcombank» and Vnesheconombank [41]. In the number of participants of the UN Global Compact Network Russia also by 2020. includes the above banks, as well as the International Investment Bank, a multilateral development institution [42].

Their commitment to the «Principles for Responsible Banking» confirmed three Russian banks: Vnesheconombank, PJSC «Sovcombank» и PJSC KB «Center Invest» [43]. Support for agricultural development in the Russian Federation is provided by VTB Bank and VTB Group as a whole, including within the framework of a cooperation agreement concluded with the Ministry of Agriculture of the Russian Federation, implying comprehensive support for the agricultural sector and increasing the availability of financing for agricultural enterprises [44]. Vnesheconombank (VEB.RF) provides guarantee and credit support to agriculture [45].

In 2019, Sberbank continued to work under the program of preferential lending to agricultural producers, launched by the Russian Ministry of Agriculture in 2017 [46], along with this, in 2019, socially significant projects in the field of agriculture were financed [46].

PJSC KB «Center Invest» has been supporting agriculture for a number of years, focusing on ideas of ESG-banking, considering environmental, social and managerial factors. It is reflected in the annual activity reports of PJSC KB «Center Invest» in this direction [41].

To the beginning of $2019,34.3 \%$ of the lending portfolio granted to legal entities in PJSC $\mathrm{KB}$ «Center Invest», accounted for lending to agriculture [48]. $76 \%$ of credit investments to support projects for the introduction of energy-efficient technologies in 2018 accounted for agriculture [48].

According to the results by October 1, 2019 in the lending portfolio of PJSC KB «Center Invest» $38 \%$ of lending came from companies related to agriculture. At the same time, the bank is involved in the implementation of the program of the Ministry of Agriculture of Russia on preferential lending to agricultural producers [49].

\section{Discussion}

The study allows to conduct that the idea of sustainable, responsible banking has not yet been disseminated throughout the Russian Federation, especially with regard to lending to agriculture. In this regard, it seems appropriate to draw attention to the need to implement the ideas of sustainable banking, the principles of responsible banking in order to activate bank lending in the Russian Federation. Taking into account modern Russian realities, it seems appropriate to formulate the following recommendations aimed at developing bank lending to agriculture in the Russian Federation based on the principles of responsible banking, aimed at achieving sustainable development goals: 
a) consider signing the UN Responsible Banking Principles by JSC «Russian Agricultural Bank»;

b) development of measures aimed at introducing a new banking practice in JSC «Russian Agricultural Bank» that takes into account the Responsible Banking Principles;

c) adoption of regulatory documents at the level of the Central Bank of the Russian Federation aimed at supporting the transition of Russian banks to the implementation of the Responsible Banking Principles, with regard to agricultural support. In this regard, it can be proposed considering the advisability of banks to consider when considering loan applications from agricultural enterprises the results of their inclusion in the ratings, reflecting the pursuit of sustainable development goals by these companies.

d) development of recommendations aimed at pursuing an internal banking policy aimed at achieving sustainable development goals, including with regard to lending to agriculture by associations of Russian banks;

e) orientation of VEB.RF, PJSC Sberbank and JSC SME Bank to support agricultural enterprises, agricultural producers committed to the ideas of sustainable development. An important aspect is the development of specialized lending products for this category of borrowers in such banks as JSC «Russian Agricultural Bank», PJSC Sberbank, and JSC SME Bank.

\section{Conclusions}

The study summarizes the international experience of establishing sustainable banking, focused on achieving the sustainable development goals declared by the UN. The features of bank lending to agriculture are identified taking into account the focus on achieving sustainable development goals. The Russian experience of sustainable banking, bank lending to agriculture based on the principles of sustainable banking is summarized. The conducted study made it possible to develop recommendations aimed at enhancing agricultural lending in the Russian Federation based on banking focused on sustainable development goals.

\section{References}

1. Resolution adopted by the General Assembly on 25 September 2015. Transforming our world: the 2030 Agenda for Sustainable Development (2015) https://undocs.org/en/A/RES/70/1

2. Addis Ababa Action Agenda of the Third International Conference on Financing for Development (Addis Ababa Action Agenda) (United Nations New York, 2015) https://sustainabledevelopment.un.org/index.php?page $=$ view\&type $=400 \& n r=2051 \& \mathrm{me}$ $\underline{\mathrm{nu}=35}$

3. A.V. Kanaev, O.A. Kanaeva, St. Petersburg University Journal of Economic Studies 35(3), 448-479 (2019) https://doi.org/10.21638/spbu05.2019.306

4. D.R. Taruna, T.P. Mahdevi, Procedia - Social and Behavioral Sciences 224, 483-490 (2016) https://www.sciencedirect.com/science/article/pii/S1877042816305080

5. A.W.H. Yip, N.M.P. Bocken, Journal of Cleaner Production 174, 150-169 (2018) https://doi.org/10.1016/j.jclepro.2017.10.190

6. D. Carlucci, F.A.F. Ferreira, G. Schiuma, M.S. Jalali, N.J.S. António, Technological and Economic Development of Economy 24(4), 1303-1322 (2018) https://doi.org/10.3846/20294913.2016.1266412 
7. Y.F. Gallagherb, K.P. Greening, Ecological Economics 154, 189-200 (2018) https://doi.org/10.1016/j.ecolecon.2018.07.009

8. W.T. Selmier, Policy and Society 35(3), 253-267 https://doi.org/10.1016/j.polsoc.2016.09.004

9. I-M. García-Sánchez, L. Rodríguez-Ariza, B. Aibar-Guzmán, C. Aibar-Guzmán, Bus Strat Env., 1- 18 (2020) https://doi.org/10.1002/bse.2485

10. V. Pirmana, A.S. Alisjahbana, R. Hoekstra, A. Tukker, Sustainability 11(22), 6417 (2019) https://doi.org/10.3390/su11226417

11. S. Nosratabadi, G. Pinter, A. Mosavi, S. Semperger, Sustainability 12(6), 2314 (2020) https://doi.org/10.3390/su12062314

12. M.M. Miralles-Quirós, J.L. Miralles-Quirós, J. Redondo-Hernández, Corp Soc Resp Env Ma. 26, 1446- 1456 (2019) https://doi.org/10.1002/csr.1759

13. G. Ibe-enwo, N. Igbudu, Z. Garanti, T. Popoola, Sustainability 11(17), 4651 (2019) DOI: $10.3390 /$ su1 1174651

14. J. Alonso-Canadas, L. Saraite-Sariene, A. Haro-de-Rosario, M.D. Caba-Perez, REICERevista Electronica de Investigacion en Ciencias Economicas 6(11), $49-75$ (2018) DOI: $10.5377 /$ reice.v6i11.6148

15. B. Burhanudin, R. Ronny, E.T. Sihotang, Procedia Computer Science 161, 341-349 (2019) https://doi.org/10.1016/j.procs.2019.11.132

16. G. Friede, T. Busch, A. Bassen, Journal of Sustainable Finance \& Investment 5(4), 210-233 (2015) DOI: $\underline{10.1080 / 20430795.2015 .1118917}$

17. H. Gonenc, B. Scholtens, Sustainability 11(12) (2019) DOI: 10.3390/su11123329

18. I. Gallego-Álvarez, M.C. Pucheta-Martínez, Bus Strat Env. 29, 347-360 (2020) https://doi.org/10.1002/bse.2368

19. M. Anshari, M.N. Almunawar, M. Masri, M. Hamdan, Energy Procedia 156, 234-238 (2019) https://doi.org/10.1016/j.egypro.2018.11.134

20. Annual report 2019. Ending Poverty, Investing in Opportunity. The World Bank, https://www.worldbank.org/en/about/annual-report

21. J.H.P.P. Eustachio, A.C.F. Caldana, L.B. Liboni, D.P. Martinelli, Journal of Cleaner Production 241, 118383 (2019) https://doi.org/10.1016/j.jclepro.2019.118383

22. Agriculture, forestry, and fishing, value added per worker (constant 2010 US\$), https://databank.worldbank.org/source/sustainable-development-goals(sdgs)/Type/TABLE/preview/on\#

23. FMO - reporting center. URL: https://reporting.fmo.nl/

24. KfW Roadmap Sustainable Finance. Das SDG-Mapping der KfW Bankengruppe. Hintergrundinformationen und Methodikerläuterung (2019) https://www.kfw.de/nachhaltigkeit/Dokumente/Sonstiges/SDG-Methodenpapier-DEEN.pdf

25. Latin America \& Caribbean. Green finance state of the market (2019) https://www.greenfinancelac.org/lac-green-finance-state-of-the-market/

26. Global Agriculture and Food Security Program, https://www.gafspfund.org/about

27. Sustainable Agribusiness (International Finance Corporation (IFC), World Bank Group)

https://www.ifc.org/wps/wcm/connect/topics_ext_content/ifc_external_corporate_site/s ustainability-at-ifc/company-resources/sustainable-agri/sustainable-agri 
28. Global Map of Environmental \& Social Risk in Agro-commodity Production (International Finance Corporation (IFC), World Bank Group) https://gmaptool.org/

29. Network for Greening the Financial System. Annual report 2019, https://www.ngfs.net/sites/default/files/medias/documents/ngfs annual report_2019.pd $\underline{\mathrm{f}}$

30. Global Alliance for Banking on Values. Annual report 2019, http://www.gabv.org/about-us/annual-reports

31. M.E. Serrano Pérez, Contaduría y Administración 62, 1393-1407 (2017) http://dx.doi.org/10.1016/j.cya.2017.06.015

32. Global progress report of the Sustainable Banking Network. Innovations in Policy and Industry Actions in Emerging 2019, https://www.ifc.org/wps/wcm/connect/227d98d4-13ae-4742-ae94-

fb248b84f0be/SBN\%2BGlobal\%2BProgress\%2BReport 1010.pdf?MOD=AJPERES\& $\underline{\mathrm{CVID}}=\mathrm{mUhlWWP}$

33. Agricultural investments for more productivity and sustainability, https://www.db.com/cr/en/concrete-Agricultural-investments-for-more-productivityand-sustainability.htm

34. Sustainable banking. Офищиальный caŭm Crédit Agricole Corporate and Investment Bank, https://www.ca-cib.com/our-solutions/sustainable-banking

35. Action Plan: Financing Sustainable Growth (European commission, Brussels, 2018) https://eur-lex.europa.eu/legalcontent/EN/TXT/PDF/?uri=CELEX:52018DC0097\&from=EN

36. Principles for Responsible Banking. Guidance Document (UNEP FI, 2019) https://www.unepfi.org/wordpress/wp-content/uploads/2019/09/PRB-GuidanceDocument-Final-19092019.pdf

37. Principles for responsible banking, https://www.unepfi.org/banking/bankingprinciples/

38. Banking. UNEP Finance Initiative, https://www.unepfi.org/banking/banking/

39. Principles for Responsible Banking. Guidance Document: Impact Analysis (UNEP FI, 2020)

https://www.unepfi.org/wordpress/wpcontent/uploads/2020/03/Guidance Document_Impact_Analysis.pdf

40. Guiding you through your sustainability journey (United Nations Global Compact, 2020)

https://d306pr3pise04h.cloudfront.net/docs/publications\%2FUN_Global_Compact_Bro chure Final Jan 2020.pdf

41. Our Participants. UN Global Compact, https://www.unglobalcompact.org/what-isgc/participants

42. Participants. UN Global http://www.globalcompact.ru/participants/

43. Banking members. UNEP Finance Initiative, https://www.unepfi.org/banking/banking/banking-members/

44. Consolidating for growth. VTB Group Sustainability report 2018, https://www.vtb.com/akcionery-i-investory/raskrytie-informacii/godovoj-i-socialnyjotchet/

45. Building a new economy for Russia. VEB.RF Group non-financial report 2018, https://xn--90ab5f.xn--p1ai/files/?file=5d3055e093602da8912f238e6ed500ee.pdf 
46. Sberbank - annual report 2019. Management report. Sustainability (ESG) report, https://www.sberbank.com/common/img/uploaded/files/pdf/yrep/sberbank-ar19eng.pdf

47. ESG-banking made in Russia, https://www.centrinvest.ru/ru/investors/esg/ESGbanking

48. Center-invest Bank, Annual environmental report 2018, https://www.centrinvest.ru/files/en-reports/env-report-2018.pdf

49. ESG - Banking: made in Russia. 9 months of 2019, https://www.centrinvest.ru/files/about/presentations/2019-9.pdf 